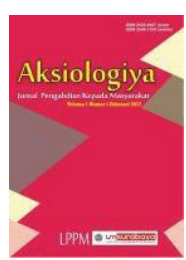

Aksiologiya: Jurnal Pengabdian Kepada Masyarakat

Vol.5, No. 1, Februari 2021 Hal 9 - 18

ISSN 2528-4967 (print) dan ISSN 2548-219X (online)

\title{
Pedampingan terhadap Tukang Ojek Muaro Panjalinan Padang dalam Meningkatkan Kemampuan Membaca al-Quran
}

\author{
Mahyudin Ritonga ${ }^{1}$, Fitri Alrasi ${ }^{2}$, Bambang $^{3}$, Yoni Marlius ${ }^{4}$, Sri Wahyuni ${ }^{5}$, \\ Elvia Susanti, ${ }^{6}$ Vivi Lorenza ${ }^{7}$ \\ 1,2,3,4,5 Dosen Prodi Pendidikan Bahasa Arab, Universitas Muhammadiyah \\ Sumatera Barat \\ ${ }^{6,7}$ Mahasiswa Prodi Pendidikan Bahasa Arab, Universitas Muhammadiyah \\ Sumatera Barat \\ Email :mahyudinritonga@gmail.com, fitrialrasi@gmail.com
}

\begin{abstract}
ABSTRAK
Tukang ojek yang ada di pangkalan Muaro Panjalinan adalah sebuah komunitas yang keberadaannya masih eksis walaupun gojek tersebar di mana-mana, namun dari sikap dan tutur kata yang mereka gunakan sehari-hari memerlukan pembinaan dalam berbagai aspek, terutama dalam bidang pemahaman keagamaan pada berbagai aspeknya. Tujuan kegiatan ini ialah untuk memberikan dampingan terhadap tukang ojek yang belum mahir dalam membaca al-Quran, kegiatan pengabdian ini diharapkan dapat meningkatkan kemampuan mereka dalam membaca alQuran. Metode pelaksanaan yang digunakan ialah metode iqro', yakni mengumpulkan tukang ojek setiap hari Jumat dan Minggu di Masjid Al-Furqon Simpang Muaro. Pelaksana kegiatan terdiri dari dosen dan mahasiswa Program Studi Pendidikan Bahasa Arab Universitas Muhammadiyah Sumatera Barat. Hasil kegiatan menunjukkan adanya peningkatan kemampuan tukang ojek dalam membaca al-Quran, hal ini dibuktikan dari enam belas tukang ojek yang awalnya hanya mampu membaca al-Quran dengan baik hanya dua orang, tapi di akhir kegiatan sudah menjadi dua belas orang. Selain itu, empat orang yang pada awal kegiatan hanya mengenal huruf hijaiyah di akhir kegiatan sudah mampu membaca al-Quran walaupun belum lancar. Kendala yang dihadapi dalam pelaksanaan kegiatan ialah masih ada di antara mereka yang lebih memilih meninggalkan kegiatan pendampingan ketika ada penumpang yang datang.
\end{abstract}

Kata Kunci: al-Quran, membaca; meningkatkan; pendampingan; tukang ojek.

\section{For Muaro Panjalinan Padang Motorcycle Taxi Drivers In Improving The Ability To Read The Koran}

\begin{abstract}
The motorcycle taxi drivers at the Muaro Panjalinan base are a community that is still a gois that is scattered everywhere, but from the attitude and speech they use everyday. The purpose of this activity is to provide assistance to motorcycle taxi drivers who are not proficient in reading the Koran, this service is expected to improve their ability to read the Koran. The implementation method used is halaqah, which is the gathering of motorcycle taxi drivers every Friday and Sunday at Al-Furqon Mosque Simpang Muaro. The event organizer consisted of lecturers and students of the Arabic Language Study Program at the University of Muhammadiyah, West Sumatra. The results of the activity showed an increase in the ability to read in Al-Quran, this was evidenced from the sixteen motorcycle taxi drivers who were initially only able to read the Koran with only two people, but at the end of the activity it had become twelve people. In addition, four people who initially only knew the letter hijaiyah at the end of the activity were able to read the Koran. Constraints that
\end{abstract}


move in the implementation of activities still exist among those who prefer compilation assistance activities, there are passengers who come.

Keywords: al-Quran, read; increase; accompaniment; motorcycle taxis driver.

\section{PENDAHULUAN}

Kemampuan membaca alQuran adalah tuntutan bagi setiap orang Islam, karena al-Quran merupakan sumber utama ajaran Islam dalam setiap aspek kehidupan, (Aderi, Noh, \& Tamuri, 2014) tidak mungkin bagi seorang muslim dapat menjalankan ajaran agama dengan baik jika sumber ajarannya saja tidak dapat dibacanya.

Hal yang demikian juga tidak terlepas dari bahasa al-Quran yang menggunakan bahasa Arab (Harun, 2018), sehingga masyarakat muslim yang ingin memiliki kemampuan membaca al-Quran di seluruh penjuru dunia dituntut untuk mempelajari cara membacanya.

Belajar membaca al-Quran secara garis besar dapatdiartikanmempelajari dan mengenali huruf hijaiyah, mengenali syakal, mengetahui ilmu tajwid, dan jika salah satu aspek dari yang tiga ini tidak sesuai maka dapat dipastikan arti bacaan al-Quran bisa berubah (al-Suyuthi, 2008), perubahan itu bahkan bisa terjadi sampai 180 derajat (Mahmood \& Ya'qub, 2016). Maksudnya ialah arti yang seharusnya positif bisa menjadi negatif atau sebaliknya, arti yang seharusnya larangan bisa menjadi perintah.

Urgensi mempelajari al-Quran sebagaimana dijelaskan di atas belum memberikan motivasi bagi sebagian umat Islam untuk mempelajarinya. Salah satunya dapat dilihat dari masih tingginya persentase umat Islam yang belum memiliki kemampuan yang baik dalam membaca al-Quran. Seperti halnya yang terjadi pada tukang ojek yang mangkal di Simpang Muaro Panjalinan Padang.

Tukang ojek yang terdapat di Muaro Panjalinan sampai September 2019 ialah sebanyak enam belas orang. Dari jumlah tersebut terdapat hanya dua orang yang mampu membaca alQuran dengan baik, bahkan yang lebih memprihatinkan masih ada empat orang lagi yang belum mengenal huruf hijaiyah secara benar. Untuk itu dibutuhkan pendampingan dalam bentuk bimbingan agar mereka dapat membaca al-Quran.

Untuk mengajarkan cara membaca al-Quran dibutuhkan metode yang tepat guna mempercepat dan memaksimalkan kualitas pengajaran (Srijatun, 2017), begitu juga dibutuhkan strategi yang tepat (Wael, Asnur, \& Ibrahim, 2018). Atas dasar pemikiran ini strategi dan pendekatan melalui pendampingan dipandang tepat sesuai dengan objek dampingan.

Sebenarnya, tempat untuk memdapatkan pembinaan dan peningkatan kemampuan membaca al-Quran cukup banyak, terutama di Sumatera Barat. Di mana selain terdapat beberapa rumah tahfiz juga setiap masjid dan mushalla memiliki TPQ/TQA atau MDA (Agustina \& Solfema, 2018). Namun, keberadaan 
beberapa lembaga tersebut ternyata tidak serta merta mengakomodir semua lapisan masyarakat, terutama masyarakat yang berusia lanjut.

Hal ini tidak terlepas dari keberadaan TPQ/TQA yang pada umumnya diperuntukkan bagi anak usia Sekolah Dasar, sehingga masyarakat umum sperti tukang ojek tidak terakomodir oleh lembaga TPQ/ TQA.

Keterbatasan tempat belajar membaca al-Quran untuk orangorang tertentu seperti tukang ojek menunjukkan pentingnya sebuah program yang sifatnya pendampingan atas inisiatif dari berbagai pihak yang memiliki kepedulian terhadap kualitas masyarakat.

Dalam artikel ini akan dijelaskan temuan pelaksanaan pengabdian pada aspek: 1) Materi yang diajarkan kepada peserta dampingan, 2) metode yang digunakan subjek pendidik, dan 3) peningkatan kemampuan objek dampingan dalam membaca alQuran.

\section{METODE PELAKSANAAN}

Pengabdian ini dilaksanakan dengan melakukan analisis situasi, identifikasi masalah, menentukan tujuan kerja sampai pada penentuan cara memecahkan masalah. Berkaitan dengan masalah yang ditemukan berkaitan dengan kemampuan membaca al-Quran yang kurang maka solusi untuk masalah tersebut dilakukan langkah-langkah sebagai berikut:

Pertama, koordniasi, yakni melakukan musyawarah dengan objek tentang kesediaan mereka untuk mengikuti sebuah program dengan waktu, tempat serta tujuan yang disepakati secara bersama.

Kedua, planning, melakukan perancangan terhadap kegiatan dampingan berupa persiapan metode, materi dan sumber Daya.

Ketiga, action, yaitu melakukan dampingan, dalam kegiatan ini metode yang digunakan ialah ialah metode iqro', yaitu dengan metode baca langsung. Adapun materi yang diajarkan ialah materi sesuai dengan yang tertuang dalam buku Iqro' yang disusun oleh KH. As'ad Humam.

Adapun sumber daya dalam kegiatan ini ialah terdiri dari: 1) Dosen program studi PBA Fakultas Agama Islam Universitas Muhammadiyah Sumatera Barat sebagai pelaksana. 2) Mahasiswa PBA sebagai fasilitator yang mempersiapkan segala yang terkait dengan administrasi dan tempat. 3) Tukang ojek yang memiliki kemampuan baca al-Quran sebagai koordinator.

Waktu pelaksanaan kegiatan pengabdian ini ialah setiap hari jumat dan minggu jam 10.0012.00 sejak bulan Februari-Agustus 2019. Adapun tempat kegiatan ialah difokuskan di masjid AlFurqon Simpang Muaro Panjalinan. Pemilihan jam sebagaimana di atas ialah dimaksudkan agar selain mereka mempelajari cara membaca al-Quran juga bisa melaksanakan shalat dhuha setidaknya dua kali dalam sepekan.

\section{HASIL DAN PEMBAHASAN}

Berdasakan kegiatan yang 
dilakukan dapat dideskripsikan bahwa hasil pengabdian ini adalah:

Pertama, materi pembinaan baca tulis al-Quran untuk tukang ojek di pangkalan Simpang Muaro Pajalinan ialah sesuai dengan yang tertuang dalam buku Iqro.

Buku iqro merupakan salah satu di antara sumber belajar membaca al-Quran yang biasa digunakan di Indonesia, bahkan buku tersebut banyak digunakan di negara lain seperti Malaysia, Brunai Darussalam dan Thailand.

Muatan materi iqro' yang digunakan sebagai sumber pembinaan baca tulis al-Quran pangkalan ojek Muaro Panjalinan ialah dapat digambarkan sebagai berikut: 1) Jilid satu mengarahkan pada pengenalan huruf hijaiyah sekaligus vokal fatah, kasrah, dan dhommah. 2) Adapun pada jilid dua ialah berkaitan dengan cara membaca huruf bersambung dengan menggunakan baris fatah dan mad asli.

Sementara pada 3) jilid ketiga ialah memuat tentang cara membaca huruf bersambung serta mad asli yang ditandai dengan huruf "ya" dan huruf "waw". Jilid ke 4) ialah berkaitan dengan baris dua (tanwin) serta bersambungnya tanwin tersebut dengan huruf izhar. Adapun 5) jilid ke lima ialah memuat hal-hal yang terkait dengan tempat berhenti (waqaf), Iqlab, Ikhfa', dan idgham. Adapun jilid 6) ialah berkaitan dengan mad far'i serta tahsin pada tingkat atas.

Dari muatan iqro' mulai dari jilid 1-6 terlihat adanya petunjuk yang jelas tentang kemampuan yang harus dicapai oleh setiap orang yang belajar membaca al-Quran dengan menggunakan buku tersebut. Sebagai gambaran cakupan materi yang diberikan, serta hari pelaksanaan dan Sumber Daya yang mendampinginya ialah dapat dilihat pada gambar.1 berikut ini:

Gambar 1. Materi pembinaan lima pertemuan awal

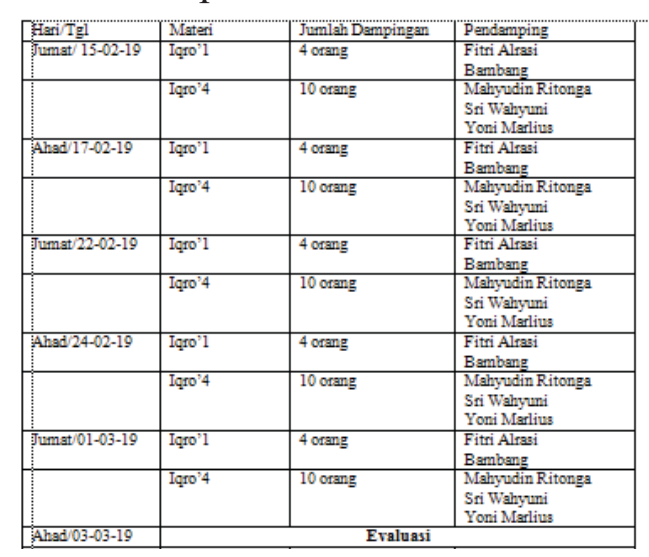

Gambar di atas menunjukkan bahwa peserta dampingan yang harus dimulai dari iqro' 1 ialah empat orang, sementara 10 orang lainnya sudah bisa dimulai dari iqro' 4, diakhir kegiatan dilakukan evaluasi penuh terhadap kemampuan peserta dampingan pada iqro'1 dan iqro' 4.

Dari hasil evaluasi terlihat peserta dampingan sudah dapat dilanjutkan ke tingkat selanjutnya. Adapun untuk pertemuan selanjutnya, materi serta pendampingnya ialah dapat dilihat dari gambar 2 sebagaimana berikut: 
Gambar 2. Materi pendampingan pertemuan 6-11

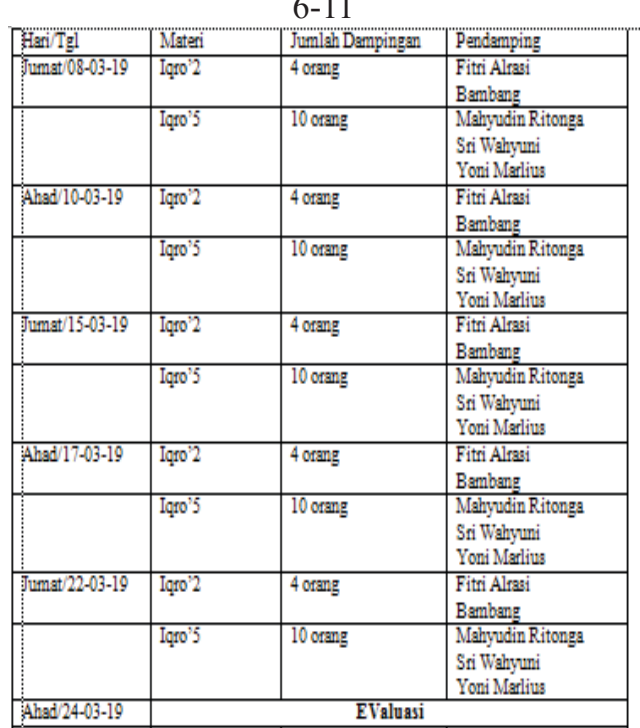

Gambar 2 di atas menunjukkan bahwa peserta dampingan pada pertemuan ke 6 sampai ke 11 pembinaan kemampuan membaca al-Quran empat orang diberikan materi dari iqro' 2 dan sepuluh orang diberikan materi iqro' 5. Sebagai pendamping terhadap empat orang sebagaimana terlihat dalam gambar di atas, Fitri Alrasi dan Bambang menjelaskan bahwa antusiasme para tukang ojek peserta pembinaan peningkatan kemampuan membaca al-Quran memberikan motivasi tersendiri kepada keduanya sebagai pendamping/pembina.

Setelah evaluasi dilakukan terhadap kemampuan peserta dampingan pada pertemuan ke 6-11 sebagaimana di atas, kemudian dilanjutkan ke materi pada jilid selanjutnya sebagaimana terlihat pada gambar 3 berikut ini:
Gambar 3. Materi pembinaan pertemuan 12-17

\begin{tabular}{|c|c|c|c|}
\hline Hari Tgl & Materi & Jumlah Dampingan & Pendamping \\
\hline \multirow[t]{2}{*}{ umat $29-03-19$} & Iqro'3 & 4 orang & $\begin{array}{l}\text { Fitri Alrasi } \\
\text { Bambeng }\end{array}$ \\
\hline & Iqro'6 & 10 orang & $\begin{array}{l}\text { Mahyudin Ritonga } \\
\text { Sri Wahyuni } \\
\text { Yoni Marlius } \\
\end{array}$ \\
\hline \multirow[t]{2}{*}{ Ahad $31-03-19$} & Iqro'3 & 4 orang & $\begin{array}{l}\text { Fitri Alrasi } \\
\text { Bambang }\end{array}$ \\
\hline & Iqro'6 & 10 orang & $\begin{array}{l}\text { Mahyudin Ritonga } \\
\text { Sri Wahyuni } \\
\text { Yoni Marlius }\end{array}$ \\
\hline \multirow[t]{2}{*}{ Tumat 05-04-19 } & Iqro'3 & 4 orang & $\begin{array}{l}\text { Fitri Alrasi } \\
\text { Bambang }\end{array}$ \\
\hline & Iqgo'6 & 10 orang & $\begin{array}{l}\text { Mahyudin Ritonga } \\
\text { Sri Wahyuni } \\
\text { Yoni Marlius }\end{array}$ \\
\hline \multirow[t]{2}{*}{ Ahad 07-04-19 } & Iqro'3 & 4 orang & $\begin{array}{l}\text { Fitri Alrasi } \\
\text { Bambang }\end{array}$ \\
\hline & Iqro'6 & 10 orang & $\begin{array}{l}\text { Mahyvdin Ritonga } \\
\text { Sri Wahyuni } \\
\text { Yoni Marlius }\end{array}$ \\
\hline \multirow[t]{2}{*}{ Tumat $12-04-19$} & Iqro'3 & 4 orang & $\begin{array}{l}\text { Fitri Alrasi } \\
\text { Bambang }\end{array}$ \\
\hline & Iqro'6 & 10 orang & $\begin{array}{l}\text { Mahyudin Ritonga } \\
\text { Sri Wahyuni } \\
\text { Yoni Marlius }\end{array}$ \\
\hline Ahad 14-04-19 & \multicolumn{3}{|c|}{ Evaluasi } \\
\hline
\end{tabular}

Dari gambar di atas dapat dipahami bahwa kemampuan peserta dampingan dalam menerima materi dari awal sampai pada pertemuan ke 17 ini cukup merata, dimana dari hasil evaluasi diketahui belum ada yang harus mengulang materi ke iqro' 2 atau ke iqro 5. Menurut Yoni Marlius, sebagai pendamping peningkatan kemampuan tukang ojek dalam membaca al-Quran dia melihat adanya penyesalan yang besar dari para peserta dampingan, sehingga kesempatan untuk belajar tidak mau mereka lewatkan begitu saja.

Adapun materi dampingan pada pertemuan selanjutnya ialah terlihat dari gambar 4, sebagaimana berikut ini: 
Gambar 4. Materi Pendampingan peningkatan kemampuan membaca

al-Quran pertemuan 18-23

\begin{tabular}{|c|c|c|c|}
\hline Ḧrai Tgl & Materi & Jumlah Drampingan & Pendamping \\
\hline \multirow[t]{2}{*}{ Jumat $19-04-19$} & Igro' 4 & 4 orang & $\begin{array}{l}\text { Fitri Alrasi } \\
\text { Bambang }\end{array}$ \\
\hline & \begin{tabular}{|l|} 
Tahsin 1 \\
\end{tabular} & 10 orang & $\begin{array}{l}\text { Mahyudin Ritonga } \\
\text { Sri Wahyuni } \\
\text { Yoni Marlius }\end{array}$ \\
\hline \multirow[t]{2}{*}{ Ahad $21.04-19$} & Igro' 4 & 4 orang & $\begin{array}{l}\text { Fitri Alrasi } \\
\text { Bambang }\end{array}$ \\
\hline & Tahsin 1 & 10 orang & $\begin{array}{l}\text { Mahyudin Ritonga } \\
\text { Sri Wahyuni } \\
\text { Yoni Mralius }\end{array}$ \\
\hline \multirow[t]{2}{*}{ urmat $26.04 \cdot 19$} & Iqgro' & 4 orang & $\begin{array}{l}\text { Fitri Alrasi } \\
\text { Brmbang }\end{array}$ \\
\hline & Tahsin 1 & 10 orang & $\begin{array}{l}\text { Mahyudin Ritonga } \\
\text { Sri Wahyuni } \\
\text { Yoni Marlius }\end{array}$ \\
\hline \multirow[t]{2}{*}{ Ahad $28-04-19$} & Igro' 4 & 4 orang & $\begin{array}{l}\text { Fitri Alrasi } \\
\text { Bambang }\end{array}$ \\
\hline & Tahsin 1 & 10 orang & $\begin{array}{l}\text { Mahyudin Ritonga } \\
\text { Sri Wahyuni } \\
\text { Yoni Mrarlius }\end{array}$ \\
\hline \multirow[t]{2}{*}{ unat $05-07-19$} & Iqgo' 4 & 4 crang & $\begin{array}{l}\text { Fitri Alrasi } \\
\text { Bembang }\end{array}$ \\
\hline & \begin{tabular}{|l|} 
Tahsin 1 \\
\end{tabular} & 10 orang & $\begin{array}{l}\text { Mahyudin Ritonga } \\
\text { Sri Wahyuni } \\
\text { Yori Mralius }\end{array}$ \\
\hline Ahad 07-07-19 & \multicolumn{3}{|c|}{ Eraluasi } \\
\hline
\end{tabular}

Dari gambar 4 di atas dapat dijelaskan bahwa empat orang yang awalnya dimulai dari iqro' satu pada pertemuan ke 18 mereka sudah bisa menerima materi sebagaimana yang diajarkan pada iqro' empat. Sementara sepuluh orang sudah bisa menerima materi tahsin.

Selanjutnya, materi pendampingan pada pertemuan ke 24-29 ialah dapat dilihat sebagaimana pada gambar 5 berikut ini:
Gambar 5. Materi pendampingan peningkatan kemampuan membaca al-Quran pertemuan 24-29

\begin{tabular}{|c|c|c|c|}
\hline Heri Tgl & Nateri & Jumlah Drmpingan & Pendemping \\
\hline Tumat $12.07-19$ & Icto's & 4 orang & $\begin{array}{l}\text { Fitri Alrasi } \\
\text { Bambang }\end{array}$ \\
\hline & Tahsin Lanjutan & 10 orang & $\begin{array}{l}\text { Mahyudin Ritonga } \\
\text { Sri Wahyuni } \\
\text { Yoni Mrelius }\end{array}$ \\
\hline Ahad 14-07-19 & Igro's & 4 orang & $\begin{array}{l}\text { Fitri Alrasi } \\
\text { Bambang }\end{array}$ \\
\hline & Tahsin Lanjutan & 10 orang & $\begin{array}{l}\text { Mahyudin Ritonga } \\
\text { Sri Wahyuni } \\
\text { YoniMralius }\end{array}$ \\
\hline Jumat $19-07-19$ & Igro's & 4 carng & $\begin{array}{l}\text { Fitri Alfasi } \\
\text { Bambang }\end{array}$ \\
\hline & Tahsin Lanjutan & 10 orang & $\begin{array}{l}\text { Mahyudin Ritongs } \\
\text { Sri Wahyuni } \\
\text { Yoni Mrrlius }\end{array}$ \\
\hline Ahad 21-07-19 & Igro's & 4 orang & $\begin{array}{l}\text { Fitri Alrasi } \\
\text { Brmbang }\end{array}$ \\
\hline & Tahsin Lanjutan & 10 orang & $\begin{array}{l}\text { Mahyudin Ritonga } \\
\text { Sri Wahyuni } \\
\text { Yoni Mrerlius }\end{array}$ \\
\hline tumst $/ 26.07-19$ & Igro's & 4 corang & $\begin{array}{l}\text { Fitri Alrasi } \\
\text { Brmbang }\end{array}$ \\
\hline & Tahsin Lanjutan & 10 orang & $\begin{array}{l}\text { Mahyudin Ritonga } \\
\text { Sri Wahyuni } \\
\text { Yoni Mrrlius }\end{array}$ \\
\hline Ahad 28-07-19 & \multicolumn{3}{|c|}{ Evaluasi } \\
\hline
\end{tabular}

Dari gambar 5 di atas dapat dijelaskan bahwa peningkatan kemampuan membaca al-Quran peserta dampingan cukup signifikan, hal ini dapat terlihat dari kemampuan mereka dalam menerima materi secara berkesinambungan. Bahkan sepuluh orang di antara mereka sudah bisa mengikuti materi tahsin lanjutan yang dibina oleh Mahyudin Ritonga, Sri Wahyuni dan Yoni Marlius.

Pertemuan ke 30 pendampingan, peserta empat orang yang pada mulanya masih kesulitan mengenal huruf hijaiyah namun mereka sudah bisa mengikuti iqro' enam. Materi yang diberikan pada pertemuan ke tiga puluh ialah dapat dilihat sebagaimana gambar 6 di bawah ini: 
Gambar 6. Materi pendampingan peningkatan kemampuan membaca al-Quran pertemuan ke 30

\begin{tabular}{|c|c|c|c|}
\hline Hari $/ \mathrm{gl}$ & Materi & Jumlah Dampingan & Pendamping \\
\hline Fumat 02-08-19 & \begin{tabular}{|l|} 
Igro'6 \\
\end{tabular} & 4 crang & \begin{tabular}{|l} 
Fitri Alrasi \\
Bambang
\end{tabular} \\
\hline Ahad $04-08-19$ & Tahsin Lanjutan & 10 orang & $\begin{array}{l}\text { Mahyudin Ritongs } \\
\text { Sri Wahyuni } \\
\text { Yoni Marlius }\end{array}$ \\
\hline \multirow[t]{2}{*}{ Tumat 09-08-19 } & Igro'6 & 4 orang & $\begin{array}{l}\text { Fitri Alrasi } \\
\text { Bambang }\end{array}$ \\
\hline & Tahssin Lanjutan & 10 orang & $\begin{array}{l}\text { Mahhudin Ritonga } \\
\text { Shi Wahyuni } \\
\text { Yoni Marlius }\end{array}$ \\
\hline \multirow[t]{2}{*}{ Ahad 11-08-19 } & \begin{tabular}{|l|} 
Igro'6 \\
\end{tabular} & 4 orang & \begin{tabular}{|l} 
Fitri Alrasi \\
Bambang
\end{tabular} \\
\hline & \begin{tabular}{|l|l} 
Tahsin Larjutan \\
\end{tabular} & 10 orang & $\begin{array}{l}\text { Mahyudin Ritongs } \\
\text { Sri Wahyuni } \\
\text { Yoni Marlius }\end{array}$ \\
\hline
\end{tabular}

Pemahaman yang dapat diambil dari gambar 6 di atas ialah bahwa pertemuan untuk mematangkan iqro' enam bagi peserta dampingan cukup empat kali pertemuan, hal ini tidak terlepas dari kontiniuitas materi yang diajarkan sehingga peserta dampingan tidak kesulitan dalam menerima dan menyerap materi.

Selain itu, kemeriahan bagi tukang ojek pangkalan Muaro Panjalinan untuk Hari Ulang Tahun Republik Indonesia pada tahun 2019 ialah ditandai dengan Khatam alQuran para tukang ojek Pangkalan Muaro Panjalinan, tepatnya 16 Agustus 2019.

Materi sebagaimana dijelaskan di atas ialah mulai dari pengenalan huruf hijaiyah. Materi ini diajarkan kepada peserta dampingan yang belum mengenal huruf hijaiyah secara baik dan benar. Pada kegiatan ini terdapat empat peserta dampingan yang belum mengetahui huruf hijaiyah. Menurut dampingan "semasa kecil dia tidak memiliki keinginan untuk mempelajari cara membaca al-Quran, penyesalan itu muncul pada saat ayahnyameninggal(DP1, Wawancara: 17 Februari 2019).

Pemberian materi mulai dari pengenalan huruf hijaiyah kepada dua orang dampingan terlihat sangat sesuai. Pernyataan ini didasarkan pada progres peningkatan kemampuan yang terjadi pada keduanya, di awal kegiatan belum mengenal dengan baik huruf hijaiyah serta belum mampu membedakan huruf-huruf yang relatif sama dan hanya dibedakan dengan titik, seperti mereka awalnya kesulitan membedakan $-\tau-\dot{\tau}$, dan membedakan ظـط, ,ض-ص di akhir kegiatan mereka sudah mampu membaca al-Quran walaupun belum lancar dan masih perlu perbaikan pada berbagai aspek, terutama yang terkait dengan tajwid.

Sesuai dengan teori penyusunan materi pembelajaran, pemilihan materi dimulai dari dasar ini dapat dinyatakan sesuai, karena para ahli berpendapat bahwa materi pembelajaran pada bidang apapun harus dimulai dari yang bersifat general (Zain, 2017), diawali dari yang mudah (Romansyah, 2016), (Hasyim, 2019), (Kiai, 2013).

Adapunmateripeserta dampingan lain ialah empat orang diawali dari Iqro' 4. Muatan yang terdapat dalam iqro' empat ialah secara signifikan berbeda dengan peserta dampingan yang dijelaskan di atas. Di mana pada materi ini peserta dampingan sudah masuk pada cara membaca baris dua dibaca dengan baris satu, seperti آنسح, yang ditulis dengan "hasanan" tapi cara membacanya "hasana”.

Begitu juga dalam iqro' empat ini pesertadampingan diperkenalkan baris fathatain, kasratain, dan dhommatain. Selain itu, peserta dampingan juga diperkenalkan cara membaca panjang dan pendek, pembedaan mad layn dan 
mad asli, pengenalan mim, dan nun mati dan lain-lain.

Terlepas dari muatan iqro' empat sebagaimana diajarkan kepada peserta dampingan, hasil dampingan menunjukkan bahwa materi ini cukup relevan dengan kemampuan dasar yang mereka miliki, karena keempat orang tukang ojek yang memulai dampingan dari iqro' empat pada akhir kegiatan terlihat bahwa mereka sudah mampu membaca dengan baik dan benar.

Di antara dampingan juga ada yang memulai proses pembinaan dari iqro' lima, peserta dampingan dalam hal ini telah memiliki kemampuan dasar dalam membaca al-Quran. Peserta dampingan pada posisi ini terkadang diminta keikutsertaannya dalam memberikan pengarahan kepada peserta dampingan yang belajar dari dasar.

Materi yang diajarkan sebagaimana dijelaskan di atas menurut Ma'mun adalah sesuai dengan objek dampingan, dimana seluruh aspek yang mesti diketahui oleh objek tentang cara membaca alQuran bersifat aplikatif tanpa harus mengajarkannya secara terpisah antara satu elemen dengan elemen lain (Ma'mun, 2018).

Hasil pelaksanaan yang kedua ialah dari aspek metode pembelajaran yang digunakan. Dalam melakukan dampingan subjek menggunakan metode yang sesuai dengan buku iqro, dimana pada buku tersebut dituntut bacaan langsung (Zulfitria \& Arif, 2016), keaktifan peserta dampingan, kebebasan berkomunikasi serta fleksibel.

Penggunaan metode sebagaimana dijelaskan di atas terlihat cukup efektif, pernyataan ini didasarkan pada kualitas hasil dampingan yang memiliki kemampuan membaca al-Quran, menurut Yusuf dkk terwujudnya kualitas hasil adalah indikator penggunaan metode yang tepat (Yusuf, Suharmanto, \& Murdani, 2014).

Pelaksanaan dampingan juga terlihat bahwa penggunaan metode dapat mempersingkat hasil. Biasanya kaum muslimin membutuhkan waktu yang relatif panjang untuk mampu membaca al-Quran, namun dalam proses dampingan ini waktu yang singkat tapi memberikan hasil yang banyak.

Hasil pendampingan yang ketiga ialah dapat dilihat dari peningkatan kemampuan membaca al-Quran di kalangan tukang ojek pangkalan Muaro Panjalinan. Kemampuan membaca al-Quran para tukang ojek terlihat cukup progresif. Hal ini terlihat dari kemampuan awal mereka yang rendah namun diakhir sudah merata kemampuan membaca alQuran di kalangan tukang ojek. Selain itu, waktu yang digunakan cukup pendek, namun singkatnya waktu tidak mensia-siakan hasil.

\section{SIMPULAN}

Dari uraian di atas dapat diketahui bahwa pemberian dampingan terhadap tukang ojek di pangkalan Muaro Panjalinan memberikan sumbangsih dalam meningkatkan kemampuan membaca al-Quran di kalangan 
tukang ojek. Materi dan metode yang digunakan dalam memberikan dampingan kepada tukang ojek ialah sesuai dengan tuntutan yang terdapat dalam buku iqro.

Hasil peningkatan kemampuan tukang ojek dalam membaca al-Quran ialah terlihat dari yang awalnya masih ada yang belum mengenal secara baik huruf hijaiyah namun di akhir kegiatan mereka sudah bisa membaca al-Quran. Di samping itu, mayoritas tukang ojek pada awal kegiatan belum lancar membaca al-Quran, tapi di akhir kegiatan mayoritas mereka sudah mampu membaca al-Quran dengan baik dan benar.

Kendala yang dihadapi dalam pelaksanaan pendampingan tidak terlalu berarti, walaupun dalam kegiatan masih ada di antara peserta dampingan yang menyempatkan diri untuk mengantarkan sewa namun kegigihan dan kekompakan mereka terlihat sehingga ketika selesai mengantarkan penumpang dia pun langsung bergabung kembali bersama teman-temannya yang sedang mendapatkan pendampingan. Hal itu juga tidak terlepas dari kesungguhan dua orang yang diamanahkan sebagai koordinator dalam mengkoordinir para tukang ojek dalam mengikuti pendampingan peningkatan kemampuan membaca al-Quran.

\section{DAFTAR PUSTAKA}

Aderi, M., Noh, C., \& Tamuri, A. H. (2014). The Study of Quranic Teaching and Learning: United Kingdom Experience. Mediterranean Journal of Social Sciences MCSER Publishing, Rome-Italy, 5(16), 313-317. https://doi.org/10.5901/ mjss.2014.v5n16p313

Agustina, \& Solfema. (2018). Gambaran Kedisiplinan Santri Taman Pendidikan al-Quran di Masjid Al-Hidayah Kota Solok. SPEKTRUM Jurnal Pendidikan Luar Sekolah (PLS), 1(4), 392397. https://doi.org/10.24036/ spektrumpls.v1i4.101772

Harun, Salman. (2018). Pintar Bahasa Arab Al-Quran. Jakarta: Lentera Hati.

Hasyim, M. (2019). Tathwir Maddah Maharah al-Kalam 'Ala Asas al-Tsaqafah al-Mahalliyah al-Islamiyyah. Islamika: Jurnal Keislaman Dan Ilmu Pendidikan, 1(1), 78-96.

Kiai,A. W. (2013). Textbook Selection Experiences Among Secondary School Teachers of English in Kenya. International Journal of Education and Research, 1(12), 1-16.

Ma'mun, M. A. (2018). Kajian Pembelajaran Baca Tulis Al-Qur'an. Annaba: Jurnal Pendidikan Islam, 4(1).

Mahmood, T., \& Ya'qub, M. (2016). al-Lughah al-'Arabiyyah wa Makanatuha al-'Ilmiyyah fi Fahm al-Qur'an wa Tafsirih. AlQisam Al-Arabi, 23(2), 45-68. Retrieved from http://pu.edu.pk/ images/journal/arabic/PDF/2Dr. Tahir Mahmood_v23_16. pdf

Romansyah, K. (2016). Pedoman Pemilihan dan Penyajian Bahan Ajar Mata Pelajaran Bahasa dan Sastra Indonesia. JURNAL LOGIKA, XVII(2), 59-66.

Srijatun. (2017). Implementasi Pembelajaran Baca Tulis AlQur'an Dengan Metode Iqro Pada Anak Usia Dini Di RA Perwanida Slawi Kabupaten Tegal. Nadwa: Jurnal Pendidikan Islam, 11(1), 2542. 
al-Suyuthi, Jalaluddin. (2008). alItqon fi 'Ulum al-Quran. Beirut: Dar al-Maktabah.

Wael, A., Asnur, M. N. A., \& Ibrahim, I. (2018). Exploring Students Learning Strategies in Speaking Performance. International Journal of Language Education, 2(2), 65-71. https://doi. org/10.26858/ijole.v2i1.5238

Yusuf, M. E., Suharmanto, A., \& Murdani. (2014). Penerapan Metode Pembelajaran Drill untuk Meningkatkan Hasil Belajar Peserta Didik Pada Standar Kompetensi Mengukur dengan Menggunakan ALat Ukur. Journal of Mechanical Engineering Learning, 3(2), 101-106.

Zain, M. (2017). Pengembangan Strategi Pembelajaran dan Pemilihan Bahan Ajar. Inspiratif Pendidikan, VI(1), 172-178.

Zulfitria, \& Arif, Z. (2016). Penerapan Metode Iqro Sebagai Kemampuan Dasar Membaca al-Quran di TK Hiama Kids. Unilak, 5(1), 57-66. 